\title{
Species Peculliarities of Weeds in Terms of Heavy Metal Accumulation
}

\section{Valentina Zubkova, Natalia Belozubova, Flura Arslanbekova, Albina Gapo- nenko, and Vasilisa Gorbunova}

Department of Technosphere Safety and Ecology, Russian State Social University, Wilhelm Pieck street, 4/1, Moscow 129226, Russian Federation

ORCID:

Valentina Zubkova: http://orcid.org/0000-0002-6707-5678

\section{Abstract}

Control over the accumulation of heavy metals $(\mathrm{HM})$ in agrophytocenoses is an urgent environmental problem. An obligatory component of all field agrophytocenoses are various agrobiological groups of weeds. The purpose of this work was to study the features of HM accumulation in the weed component of agrophytocenoses. The study was carried out in agrophytocenoses of the Yaroslavl region, represented by winter and

Corresponding Author: Natalia Belozubova gerlinger_natali@mail.ru

Published: 5 April 2021

Publishing services provided by Knowledge

(c) Valentina Zubkova et al. This article is distributed under the terms of the Creative Commons Attribution License, which permits unrestricted use and redistribution provided that the original author and source are credited.

Selection and Peer-review under the responsibility of the DonAgro Conference Committee.

\section{G OPEN ACCESS} spring crops, legumes, corn, industrial crops, and a wide variety of weeds. According to the data of the route survey of crops in the Yaroslavl region, the weediness of agricultural plants was 31-101 pieces per square meter. Weeds differed in the content of HMs: by 5.8 times for Zn; more than 14 times for $\mathrm{Cd}$ and $\mathrm{Pb}$; and about 6 times for $\mathrm{Cu}$. Dandelion medicinal and creeping wheatgrass expressed the barrier function of the roots in relation to all of the studied elements. The contribution of weeds to the general elimination of trace elements and heavy metals by plants of agrophytocenoses is insignificant.

Keywords: weeds, heavy metals, trace elements, barrier function of roots

\section{Introduction}

Intensive industrial and agricultural use of natural resources causes a significant change in the cycles of most chemical elements, including heavy metals (HM), control over their accumulation in plants is an important element of the state agroecological monitoring program.

Trace elements are distributed in plants and carried out by them unevenly, which is due to the physiological role of each of the elements, the specificity of biochemical processes in different parts of the plant, and the concentration of ions in the soil solution. When ions move into the above-ground organs, selective absorption mechanisms are in action, the priority belongs to physiologically important chemical elements [1, 2]. 
An obligatory component of all field agrophytocenoses is various agrobiological groups of weeds. When grown together with cultivated plants, they compete with them not only for nutrients, but also eliminate a certain amount of heavy metals from the soil $[3,4]$.

When the territory is polluted with heavy metals, the problem of clearing the land and remediating it for economic use arises. Decontamination of contaminated areas can be carried out in different ways, among which mechanical methods and purification can be distinguished due to natural geochemical and biological processes, which include the elimination of heavy metals by weeds $[5,6]$.

In this regard, the purpose of our research was to study the features of HM accumulation by the weed component of agrophytocenoses.

\section{Methods and Equipment}

The studies were carried out in agrophytocenoses of the Yaroslavl region, represented by crops of winter and spring grains (winter rye, winter and spring wheat, barley, oats), legumes, corn, industrial (fiber flax) crops, as well as a wide variety of weeds. On 10 test plots belonging to different agrophytocenoses, the species composition of weeds, the number and, subsequently, the mass of weeds by species were determined. Selected plant samples were dried to an air-dry state, crushed and analyzed on a Varian Spectr AA-240 spectrophotometer in the testing laboratory of OOO Center for Certification and Environmental Monitoring of the Moskovsky Agrochemical Service.

\section{Results}

According to the data of the route survey of crops in 2019 in the Yaroslavl region with a yield of agricultural plants, which amounted to 14.2-24.8 for winter grains, 15.7-19.2 for spring grains, 3.11 for flax (straw) and 25.0 t/ha for potatoes. The weediness of crops was 30.9-101 pieces per square meter. The species and elemental composition of weeds is presented in Table 1.

The zinc content in weeds of field phytocenoses was low and on average ranged from $8.90 \mathrm{mg} / \mathrm{kg}$ in the field sow thistle (Sonchus arvensis) to $51.7 \mathrm{mg} / \mathrm{kg}$ in the rugged knotweed (Polygonum carbumL), that is, the maximum difference was 5.81 times. Some researchers attribute this to the fact that the assimilation of zinc by plants on agricultural land decreases due to the neutralization of soil acidity due to liming and an increase in the supply of phosphorus when phosphorus fertilizers are applied. Differences for 
TABLE 1: Species and elemental composition $(\mathrm{mg} / \mathrm{kg})$ of weeds of agrophytocenoses of the Yaroslavl region

\begin{tabular}{|c|c|c|c|c|}
\hline Weeds & $\mathrm{Zn}$ & $\mathrm{Cd}$ & $\mathrm{Pb}$ & $\mathrm{Cu}$ \\
\hline \multicolumn{5}{|c|}{ Perennial non-parasitic weeds } \\
\hline Elytrigia repens $L$. & $\frac{29.3 \pm 1.6}{19.5-62}$ & $\frac{0.17}{0.06-0.27}$ & $\frac{2.03}{1.0-4.1}$ & $\frac{5.6}{2.9-8.8}$ \\
\hline Equisetum arvense & $\frac{62.7}{24.3-89.4}$ & $\frac{0.28}{0.09-0.49}$ & $\frac{3.4}{1.62-5.18}$ & $\frac{6.2}{1.81-10.32}$ \\
\hline Sonchus arvensis & $\frac{22.8}{8.5-45.3}$ & $\frac{0.16}{0.09-0.21}$ & $\frac{1.06}{0.87-2.21}$ & $\frac{3.9}{1.74-6.43}$ \\
\hline Cursium aryense & $\frac{8.9}{6.0-11.7}$ & $\frac{0.35}{0.13-0.59}$ & $\frac{4.81}{0.8-9.7}$ & $\frac{6.7}{2.1-14.2}$ \\
\hline Vicia cracca & $\frac{21.8}{19.6-32.3}$ & $\frac{0.27}{0.09-0.56}$ & $\frac{2.95}{2.1-4.6}$ & $\frac{6.98}{2.4-13.7}$ \\
\hline Convolvulus arvensis & $\frac{25}{15.3-36.4}$ & $\frac{0.09}{0.03-4.41}$ & $\frac{1.9}{0.2-8.17}$ & $\frac{7.2}{2.1-11.6}$ \\
\hline Taraxacum officinale & $\frac{19.1 \pm 2.1}{17.2-20.4}$ & $\frac{0.30}{0.19-0.31}$ & $\frac{2.20}{1.33-4.76}$ & $\frac{8.4}{7.6-11.0}$ \\
\hline \multicolumn{5}{|c|}{ Juvenile non-parasitic weeds } \\
\hline Chenopodium album & $\frac{26.4}{10.3-41.3}$ & $\frac{0.12}{0.05-0.18}$ & $\frac{0.56}{0.17-17.0}$ & $\frac{5.20}{4.4-18.7}$ \\
\hline Polygonum carbumL & $\frac{51.7}{50.5-53.2}$ & $\frac{0.10}{0.07-0.15}$ & $\frac{0.34}{0.24-0.49}$ & $\frac{8.3}{7.1-12.0}$ \\
\hline $\begin{array}{l}\text { Raphanus } \\
\text { raphanistrum L. }\end{array}$ & $\frac{32.7}{10.8-50.6}$ & $\frac{0.56}{0.13-0.9}$ & $\frac{3.11}{2.1-3.9}$ & $\frac{8.5}{5.61-12.13}$ \\
\hline Galeopsis speciose & $\frac{20.6}{2.42-40.1}$ & $\frac{0.04}{0.01-0.09}$ & $\frac{0.85}{0.28-0.57}$ & $\frac{4.13}{1.07-6.79}$ \\
\hline Echinochloa crusgalli & $\frac{17.0}{15.8-19.6}$ & $\frac{0.11}{0.03-0.22}$ & $\frac{0.64}{0.14-1.17}$ & $\frac{3.10}{1.12-}$ \\
\hline Capsella bursa-pastoris & $\frac{30.8}{26.5-35.7}$ & $\frac{0.45}{0.09-0.97}$ & $\frac{2.81}{1.25-4.8}$ & $\frac{7.03}{4.5-9.8}$ \\
\hline Matricaria perforata), & $\frac{43.7}{42.1-53.6}$ & $\frac{0.29}{0.25-0.33}$ & $\frac{2.7}{3.0-4.3}$ & $\frac{15.0}{6.2-23.6}$ \\
\hline
\end{tabular}

cadmium and lead were more significant and amounted to more than 14 times and about 6 times for copper.

The total coefficients of HM concentration in the aboveground mass, calculated in comparison with their minimum values, reached maximum values for wild radish (Raphanus raphanistrum L.), field thistle (Cursium aryense), field horsetail (Equisetum arvense), shepherd's purse (Capsella bursa-pastoris) (Table 3).

In terms of the ability to accumulate heavy metals, two contrasting groups of plants are distinguished: eliminators, in which heavy metals accumulate mainly in the root system, and accumulators, in which they accumulate in large quantities in the aboveground organs. 
TABLE 2: Total coefficients of HM concentration in relation to their minimum values in weeds of the Yaroslavl region

\begin{tabular}{l|c|l|c|}
\hline $\begin{array}{l}\text { Perennial non-parasitic } \\
\text { weeds }\end{array}$ & Zc & Juvenile non-parasitic weeds & Zc \\
\hline Elytrigia repens L. & 14.79 & Chenopodium album) & 9.30 \\
\hline Equisetum arvense & 25.82 & Polygonum carbumL & 11.99 \\
\hline Sonchus arvensis & 9.92 & Raphanus raphanistrum L. & 29.56 \\
\hline Cursium aryense & 26.06 & Galeopsis speciosa & 7.14 \\
\hline Vicia cracca & 20.13 & Echinochloa crusgalli & 7.54 \\
\hline Convolvulus arvensis & 10.47 & Capsella bursa-pastoris & 25.24 \\
\hline Taraxacum officinale & 18.83 & Matricaria perforata & 24.94
\end{tabular}

There are no barrier tissues in the roots of the accumulators, as a result of which their root system, in contrast to the eliminators, does not limit the supply of metals to the shoot.

Our study of the distribution of HMs between the organs of some weeds shows the presence of both eliminators and accumulators among them (Table 4).

TABLE 3: Distribution of HM between the organs of weeds, mg per kg of dry weight

Plant type
Common dandelion
(Taraxacum officinale)
Creeping wheatgrass
(Elytrigia repens L.)
Common horsetail
(Equisetum arvense)
Lamb's-quarters
(Chenopodium album)

$\mathrm{Zn}$
$\frac{19.3 \pm 4.1}{27.6 \pm 7.6}$
$\frac{30.0 \pm 4.2}{147 \pm 11.4}$
$\frac{26.1 \pm 2.9}{51.8 \pm 5.2}$
$\frac{24.3 \pm 2.2}{20.0 \pm 1.9}$

$\mathrm{Cd}$
$\frac{0.29 \pm 0.102}{0.31 \pm 0.109}$
$\frac{0.03 \pm 0.01}{0.11 \pm 0.02}$
$\frac{0.20 \pm 0.2}{0.05 \pm 0.01}$
$\frac{0.09 \pm 0.01}{0.05 \pm 0.01}$

$\mathrm{Pb}$
$\frac{1.51 \pm 0.56}{1.97 \pm 0.18}$
$\frac{0.11 \pm 0.03}{0.74 \pm 0.07}$
$\frac{3.6 \pm 0.3}{8.0 \pm 0.6}$
$\frac{0.17 \pm 0.02}{0.46 \pm 0.05}$

\begin{tabular}{c}
$\mathrm{Cu}$ \\
$\frac{8.1 \pm 1.9}{13.6 \pm 2.8}$ \\
$\frac{8.2 \pm 1.4}{64 \pm 0.71}$ \\
$\frac{6.1 \pm 0.5}{14.8 \pm 1.5}$ \\
$\frac{4.5 \pm 0.4}{6.0 \pm 0.5}$ \\
\hline
\end{tabular}

For instance, with a close zinc content in the studied plants, its content in the plant roots was not the same. In lamb's-quarters, the roots contained less zinc than the aboveground mass, in other plants its content in the roots sharply exceeded the content in the aboveground mass: by 1.43 times in the common dandelion (Taraxacum officinale); by 1.97 times in common horsetail (Equisetum arvense); and by 4.9 times in creeping couch grass (Elytrigia repens). In common dandelion and creeping wheatgrass, the barrier function of the roots is also expressed in relation to cadmium, lead and copper; roots of common horsetail and lamb's-quarters barrier lead and copper.

In our studies, the total elimination of the priority heavy metals by agricultural plants for the Non-Black Earth Zone amounted to $69-153 \mathrm{~g} / \mathrm{ha}$ for Zn; 0.07-0.71 g/ha for cadmium; 0.41-0.81 $\mathrm{g} / \mathrm{ha}$ for lead and $18-47 \mathrm{~g} / \mathrm{ha}$ for copper.

Under the conditions of 2019, according to the value of the aboveground mass of plants and the average content of heavy metals in it, their involvement in the cycle was 
also studied by weeds (Table 5). According to our research, depending on the type of weed plants, the elimination varied: 3.0 times for copper fluctuated, 2.2 times for zinc, 10.1 times for cadmium, 2.0 times lead.

TABLE 4: Elimination of HMs by weeds in various agrophytocenoses, g/ha, 2019*

\begin{tabular}{|l|c|c|c|c|}
\hline Agrophytocenosis & $\mathrm{Zn}$ & $\mathrm{Cd}$ & $\mathrm{Pb}$ & $\mathrm{Cu}$ \\
\hline Winter wheat & 1.56 & 0.01 & 0.09 & 0.45 \\
\hline Winter rye & 1.42 & 0.01 & 0.08 & 0.40 \\
\hline Spring wheat & 5.54 & 0.02 & 0.24 & 1.05 \\
\hline Spring barley & 3.35 & 0.01 & 0.09 & 0.63 \\
\hline Oats & 6.97 & 0.03 & 0.14 & 1.32 \\
\hline Annual herbs & 1.69 & 0.01 & 0.04 & 0.35 \\
\hline Corn for silage & 3.42 & 0.02 & 0.29 & 0.47 \\
\hline Perennial herbs & 3.32 & 0.04 & 0.80 & 0.72 \\
\hline Flax & 3.19 & 0.03 & 0.34 & 0.83 \\
\hline Potato & 1.90 & 0.01 & 0.30 & 0.34 \\
\hline
\end{tabular}

\section{Discussion}

Differences in the accumulation of HMs by plant organs can be used both to reduce the influx of HMs into the aerial part of plants and to increase their elimination during phytoremediation.

The research results indicate that some plant species are able to accumulate high concentrations of HMs and show resistance to them, while others seek to reduce the intake of HMs by maximizing their barrier functions. It is recommended to assess the ecological state of the soil-plant system by the species composition of growing plants, their ability to the accumulation of heavy metals and the species resistance of plants to soil pollution with heavy metals.

Due to the fact that certain species of weeds, and sometimes genera, can show a selective ability to accumulate trace elements and heavy metals, they differ significantly in the content of trace elements and the selectivity of their absorption (Table 1).

Understanding the reasons for the limited intake of heavy metals in the aboveground organs in eliminator plants and unlimited intake in accumulators can be used to develop methods to reduce the content of heavy metals in agricultural products, on the one hand, and to increase the content of metals in the aboveground organs of plants used in phytoremediation technology, on the other. 


\section{Conclusion}

The contribution of agrobotanical groups to the biogenic exchange of chemical elements is determined by the difference not only in the annually eliminated and dying volumes of aboveground phytomass, but also in the level of pollution, as well as in the intensity of mineralization of plant residues. Changes in the concentration of pollutant elements in the soil affect the cycle of chemical elements in agrocenoses. With an increase in the HM content in the soil, we can talk about anthropogenic deformation of this exchange.

Assessing the contribution of weeds to the total alienation of trace elements and heavy metals by plants of agrophytocenoses, it should be noted that it is not significant, averaging only $3.24 \mathrm{~g} / \mathrm{ha}$ for zinc; 0.02 for cadmium; $0.24 \mathrm{~g} / \mathrm{ha}$ for lead; $0.66 \mathrm{~g} / \mathrm{ha}$ for copper. That is, the share of weeds in the total elimination of zinc and copper does not exceed $2-3 \%, 5 \%$ for cadmium and $28 \%$ for lead. Therefore, in the technology of remediation, the studied weeds can play a certain role on soils contaminated with lead.

\section{References}

[1] Zubkova, V. M. (2013). Chemical Composition of Plants under Soil Contamination with Heavy Metals: Monograph. Moscow: Russian State Social University, p. 196.

[2] Elcheva, I. O. and Zubkova, V. M. (2019). Influence of Anthropogenic Load on the Chemical Composition of Dactilis Glomerata. Modern Science: Actual Problems of Theory and Practice. Series: Natural and Technical Sciences, vol. 3, pp. 25-30.

[3] Makarova, N. M. and Makarov, A. V. (2017). Assessment of Individual Species of Herbaceous Plants for Phytomelioration of Soils in Erosion-Hazardous Territories. Scientific Journal of the Russian Research Institute of Melioration Problems, vol. 4, issue 28 , pp. 121-136.

[4] Okazova, Z. P. (2015). The Harmfulness of Weeds in Winter Wheat Crops in the ForestSteppe Zone of the North Caucasus. Modern Problems of Science and Education, vol. 2, issue 2. pp. 1-10.

[5] Poznyak, S.S. (2011). The Content of Some Heavy Metals in the Vegetation of Field and Meadow Agrophytocenoses under Conditions of Technogenic Pollution of the Soil Cover. Bulletin of the Tomsk State University. Biology, vol. 13, issue 1, pp. 123-137.

[6] Chaplygin, V. A., et al. (2019). The Input of Zn and Cd from Soil into Herbaceous Plants of the Asteraceae and Poaceae Families. Living and Bioinert Systems, vol. 29. pp. 23-32. 